\title{
Institutional Quality, Openness, and Investment in Africa ${ }^{1}$
}

\section{Tonia Kandiero}

Department of Economics, University of Pretoria

\section{Satish Wadhawan}

Department of Economics, Howard University

\begin{abstract}
This study supports the conventional wisdom that openness to trade is good for investment and economic growth. Whether this conclusion leaves space for institutional quality as a complimentary policy to determine the success of trade liberalization in Africa is the objective of this paper. The theoretical model and empirical analysis show how the behavior of government bureaucrats can be used to explain the impact on investment of the interaction between increased openness to trade and the quality of institutions. Empirical work is conducted using panel data observed over three periods: 1985-1990, 1990-1995, and 19952000 .
\end{abstract}

JEL 017, F1, E22

\section{INTRODUCTION}

The discussion on the impact of openness to trade and institutional quality on economic performance is increasingly becoming an important topic. As countries present their modalities in the new trade agenda, complimentary policies such as institutional quality should also be taken into great consideration. On one hand, the body of literature on trade, Grossman and Helpman (1991), Edwards (1992), Ades and Glaeser (1999), Ades and Di Tella (1997a), Sachs and Warner (1995), Kruger (1974), has established that openness to trade is good for economic performance. On the other hand, a number of existing literature on institutions including North (1990), Shleifer and Vishny (1993), Mauro (1995), Knack and Keefer (1995), Nelson (1997), Hall and Jones (1999), Kandiero (2001) conclude that better institutional structure is vital for economic progress. The presence of less corruption, good property rights, and rule of law encourages innovation and investment.

This study supports the general framework that openness to trade is associated with positive economic performance. Whether this conclusion leaves space for 
institutional quality as a complimentary policy to determine the success of trade liberalization in Africa is the objective of this paper. The theoretical model and empirical analysis indicate how the behavior of government bureaucrats can be used to explain the impact on investment of the interaction between increased openness to trade and the quality of institutions. The empirical work is conducted using cross-country data observed over three periods: 1985-1990, 1990-1995, and 1995-2000. The results show that the quality of institutions has a significant impact on the success of increased openness. Controlling for variables, such as initial GDP, education levels, inflation, population growth, among others, the total impact of increased openness on investment has a positive coefficient, 2.92, while the direct impact is approximately 4 times more. A one standard deviation improvement in the interaction between institution quality and increased openness would lead to an increase in investment by 6.69 percent as opposed to 4.74 percent from openness alone. Similar results are derived when different institutional quality variables are used.

The structure of this paper is as follows: section 2 presents measurement issues regarding openness to trade and institutional quality; section 3 adopts the model by Shleifer and Vishny (1993) to explain the link between openness, institutional quality, and investment; section 4 discusses data on openness and institutional quality; section 5 explains the econometric methodology; section 6 presents scattered plots to depict a simple relationship between openness and investment, as well as the model specification and regression results; and section 7 concludes.

\section{OPENNESS TO TRADE AND THE ISSUE OF MEASUREMENT}

Existing studies on openness use different measures of openness. The most common yardsticks are trade shares of GDP, measures of price distortions, and indices of trade barriers. The use of different measures of openness has caused major concerns in regards to the validity of the empirical findings on this issue of openness.

Studies dealing with the issue of openness have presented different measures as proxies for openness to trade. For this reason, this discussion pertaining to openness has remained very controversial. Balassa (1982) applies trade dependency ratio and rate of export growth as proxies for measuring openness to trade. According to Edwards (1998), these types of indicators have limitations because a country can have trade distortion, and still have a high trade dependency ratio. Sachs and Warner (1997) present a series of trade indicators, such as tariffs, quotas coverage, black market premium, social organization, and the existence of export marketing boards as a proxy for measuring openness to 
trade. This measure was seen as a good attempt to improve the previous proxies for openness. The flaw with the approach is that it only shows whether a country is closed or open. As a result, countries with different types of trade intervention policies are perceived as open. Pritchett (1991), Anderson and Neary (1994) and Ingco (1997) have used more observable variable, such as average tariff, average coverage of quantitative restrictions (QRs) and collected tariff ratios (CTR), which are defined as ratios of tariff revenues to imports. Pritchett and Sethi (1994) find that CTR underestimates protection. In addition, the study concludes that there is no linear relationship between official tariff rate and CTR.

Dollar and Kraay (2001) explain that even for the most direct openness measures, average tariff rates or non-tariff barrier coverage ratios, they have obvious shortcomings. In the case of simple averages of tariff rates, it is possible to give inordinate weight to categories of goods that are viewed as relatively not important for a country. If one averages weighting by imports, then the effects of prohibitive tariffs on imports are lost. Pertaining to non-tariff barriers, the best available data simply report the number of tariff lines on which one of a small number of easily identifiable NTBs is in place. This type of data again does not provide information on how binding the NTBs are, and obviously excludes other less-easily quantifiable barriers to trade, such as local procurement requirements. And for all measures, there are important gaps between statutory rates and actually collected tariffs, due to both legal exemptions, poor enforcement of tariffs, or corruption in the customs administration.

Dollar (1992) is one of the most cited papers in the area of openness. The author constructs two indices: an index of real exchange distortion (DISTORTION) and an index of real exchange rate variability (VARIABILITY). These indices are said to capture the distortions and variability of "outward orientation". The author concludes that each of the indices is negatively associated with growth over the period 1976-85. One of the issues with the DISTORTION index is that it may not capture trade policy but rather exchange rate and monetary policies. Variability also captures movement of domestic prices in relation to world prices, and the distortions do not separate tradable and non-tradable goods. Therefore, these two indicators may in fact not represent the best indicators to measure openness to trade.

Using cross-country studies, Ades and Di Tella (1997a) and other recent studies have used the share of imports in GDP as a proxy of openness. The only concern with this measure is that it may not capture the openness entirely. 
It is clear that measurement issues are potentially a problem for all variables, but it is especially acute for openness variables. Since it still appears to be difficult to find reliable systematic data on trade policies across countries, many papers, including Dollar and Kraay (2001), have instead simply included trade volumes (exports plus imports as a share of GDP) as one of the explanatory variables in a cross-country regression. For this particular purpose of looking at the effects of the interaction between trade and institution on growth, this imperfect proxy for openness, certainly is sufficient.

As mentioned earlier, countries under investigation are divided into two groups. Countries with openness greater than the mean are assigned a dummy variable of 1 and countries with openness less than the mean are assigned the value 0 . The main reason for dividing the countries into two categories is to make the strong argument that benefits from increased openness could be reduced by the quality of institutions.

\section{CONCEPTUAL FRAMEWORK}

The framework presents a single bureaucratic problem by utilizing a simple model presented by Shleifer and Vishny (1993). The model assumes that the government manufactures a homogeneous good, Y, such as an export license or import license. The quantity of the sales of the good is a function of price the bureaucrat charges

$$
\begin{aligned}
& \mathrm{Y}=\mathrm{F}(\mathrm{p}) \\
& \mathrm{dY} / \mathrm{dp}<0
\end{aligned}
$$

and expressing price as a function of quantity

$$
\begin{aligned}
& \mathrm{p}=\mathrm{G}(\mathrm{Y}) \\
& \text { Where dp/dY }<0
\end{aligned}
$$

The demand function is assumed to be negatively sloping. As the price increases, the quantity demanded by the private sector decreases. The demand function of the license or public good is assumed to be affected by increase in trade. An increase in trade in this respect is said to affect the demand for the public good. The bureaucrats are in charge of selling this public good, and they can determine how much they can sell. The bureaucrats can choose to delay the process of obtaining the good in order to receive a bribe from the private agent ${ }^{2}$. The model assumes that the bureaucrats operate in an environment where they can choose not to supply the good without the risk of getting a penalty. Essentially, the corrupt bureaucrats have very little or no chance of facing a punishment ${ }^{3}$. Again, the model depends on the assumption that informal 
sanctions associated with religious dictates or moral norms constrain agents from too much opportunism.

Another assumptions in this theoretical framework is that government corruption occurs without theft. Even though the market is competitive, the bureaucrats are assumed to act as a monopoly because they have the power to set the price of the good. In this regard, the public official sets the price of the good as follows:

$$
\mathrm{P}=\mathrm{p}+\phi
$$

where $\mathrm{P}$ is the total price of the good, $\mathrm{p}$ is the price charged by the government, and $\phi$ is the bribe that the bureaucrats add on the initial price. In this respect, the bribe inflates the price of the good, which entails an increase in the transaction cost. The public official is not concerned with the cost of producing the public good since the government incurs the cost. To find the marginal cost in the case of corruption without theft, the public official gives the government the initial or the official price, $\mathrm{p}$, and keeps the bribe. Therefore, the marginal cost of providing the export or import license is equal to the official price

$$
\mathrm{MC}=\mathrm{p},
$$

where $\mathrm{MC}$ is marginal cost and $\mathrm{p}$ is the price offered by the government. As a result of this restrictive assumption, the $\mathrm{MC}$ line is a horizontal line. The bureaucrat's total revenue, $(\mathrm{R})$ is

$$
\mathrm{R}=\mathrm{PY},
$$

and, the marginal revenue, MR, is derived by differentiating equation (7) with respect to good, Y.

$$
\mathrm{MR}=\mathrm{dR} / \mathrm{dY}=\mathrm{P}+\mathrm{Y}(\mathrm{dp} / \mathrm{d} \mathrm{Y}) .
$$

Since $d p / d Y<0$, marginal revenue, MR is said to be less than price. The bureaucrat as a monopoly is assumed not to engage in price discrimination. Therefore, profit for the bureaucrat point is as follows:

$$
\Pi=\mathrm{TR}-\mathrm{TC} .
$$

The profit maximization for the bureaucrat is the difference between marginal cost and marginal revenue 
(10)

$$
\Pi \max =\mathrm{d} \Pi / \mathrm{dY}=\mathrm{MR}-\mathrm{MC}=0
$$

The second order condition of the maximization problem is

$$
\mathrm{d}^{2} \Pi / \mathrm{d} \mathrm{Y}^{2}<0 .
$$

The demand for the good in the face of a bribe is able to hold because the market structure does not allow bureaucrats to compete for bribes. Competition by bureaucrats would force the bribe to be reduced (Ades \& Di Tella (1997b)). Figure 1 is the graphical presentation of the problem.

The destructive nature of transaction cost after opening the economy depends on how much the aggregate demand curve shifts and the elasticity of demand. If the shift is small, then the price plus the transaction cost would be below $(p+$ bribe) [see Appendix 1]. Also, if the demand curve was more elastic (more horizontal), then the total cost after the bribe would be below $p+$ bribe. Nevertheless, the transaction cost in the presence of rents is still higher than the price charged by the government.

\section{Figure 1 Corruption and openness to trade}

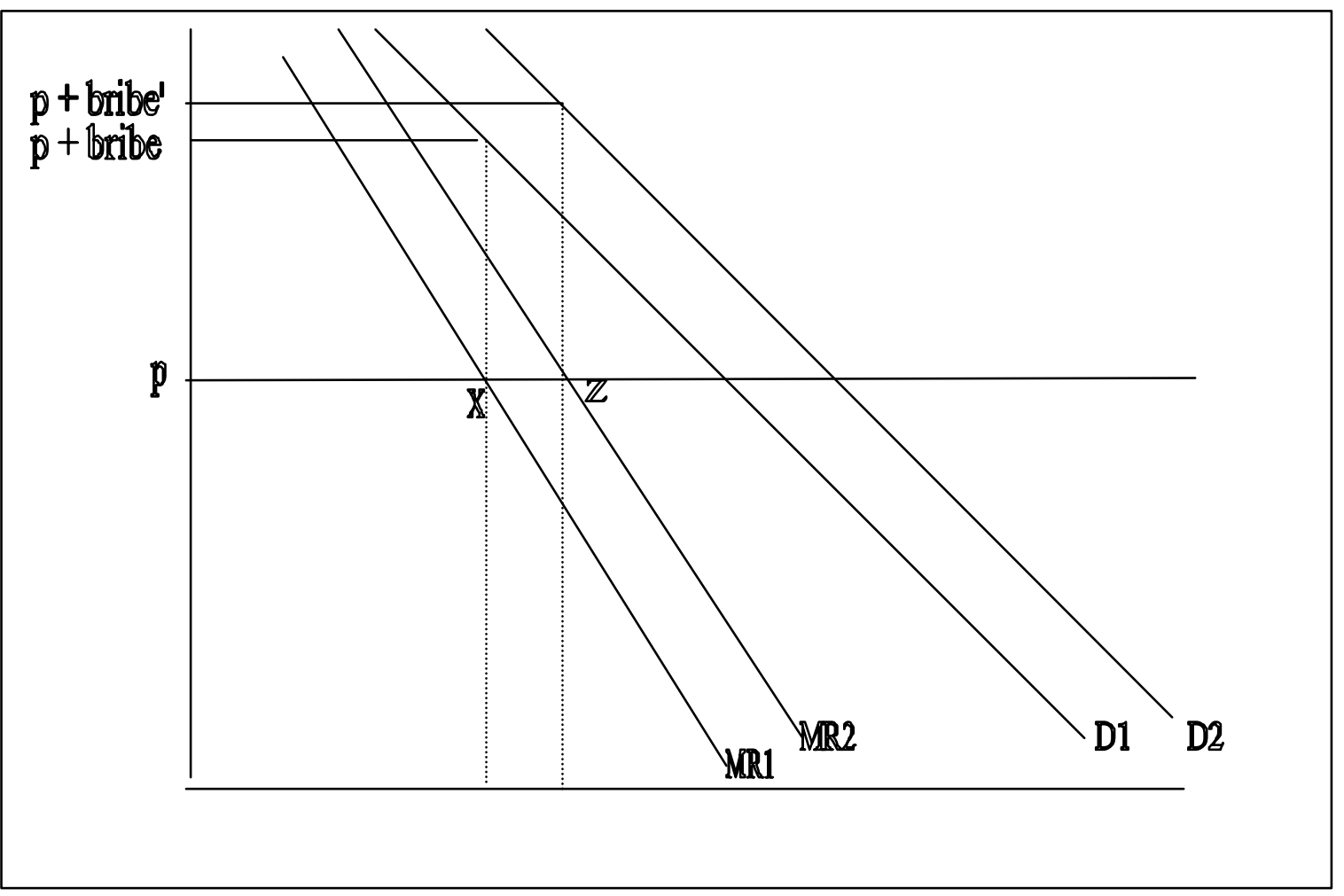


Increased openness in the presence of poor institutional quality as characterized by corruption, weak rule of law, red tape and poor contract enforcement policies may encourage more rent-seeking behavior by the bureaucrats. The consequence would be a diversion of resources from productive resources to the rent-seeking sector. Therefore, the moral of the story is that, even though the agent does not steal from the government, the increase in the transaction cost through bribes increases transaction costs for the private agents, leading to lower investment.

This theoretical argument is confirmed empirically. The findings indicate that full benefits of increased openness on investment can be reduced by the quality of institutions. This case can be improved if corrupt bureaucrats are penalized for engaging in rent-seeking activities. According to Shleifer and Vishny (1993), if the expected penalty imposed by the government increases with the level of bribe, the public agent may reduce the bribe. In addition, in the case where the public officials compete for rents, an increase in openness may result in a reduction of bribes making openness more favorable for economic performance (Becker \& Stigler, 1974; Rose-Ackerman, 1978; Ades \& Di Tella, 1997b).

\section{OPENNESS TO TRADE AND INSTITUTIONAL QUALITY DATA}

The principal idea of this section is to show that underdeveloped institutions can reduce potential benefits from increased openness to trade. As mentioned earlier, the dummy variable 1 represents all the countries with openness to trade more than the mean, while 0 captures all the countries considered less open. Table 1 shows that a little less than half of the countries in the sample have the openness variable above the mean, while the rest of the countries fall below the mean.

\section{Table 1 Openness to trade dummy variables}

\begin{tabular}{||l|l||}
\hline \multicolumn{1}{|c|}{ Dummy =1 } & \multicolumn{1}{c|}{ Dummy = 0 } \\
\hline Angola & Algeria \\
\hline Botswana & Bukina Faso \\
\hline Congo DRC & Cameroon \\
\hline Gabon & Congo Republic \\
\hline The Gambia & Egypt \\
\hline Ghana & Ethiopia \\
\hline Cote d'Ivoire & Guinea \\
\hline Madagascar & Kenya \\
\hline Malawi & Mali \\
\hline
\end{tabular}


Table 1 continued

\begin{tabular}{||l|l||}
\hline \multicolumn{1}{|c|}{ Dummy = 1 } & \multicolumn{1}{c||}{ Dummy = 0 } \\
\hline Mozambique & Morocco \\
\hline Nigeria & Namibia \\
\hline Sierra Leone & Niger \\
\hline South Africa & Senegal \\
\hline Tunisia & Sudan \\
\hline Uganda & Tanzania \\
\hline Zimbabwe & Togo \\
\hline & Zambia \\
\hline
\end{tabular}

Some of the relatively open countries include South Africa, Botswana, Ghana, Malawi, Cote d'Ivoire, just to mention a few. Most of the countries in North Africa, for example, Egypt, Algeria, and Morocco, are considered relatively less open.

Institutional Quality Data: An aggregate of corruption index, bureaucratic quality, rule of law, and investment profile variables are used as a proxy for institutional quality. The data is from the International Country Risk Guide (ICRG), a monthly publication by the Political Risk Services ${ }^{5}$.

Corruption: This variable represents the degree of corruption in government. Corruption is defined as demands for special payments and bribes in connection with import and export licenses, exchange controls, tax assessment, or loans. Data range is from 0 to 6 with 0 being highest corruption and 6 lowest corruption.

Bureaucracy Quality (BQ): This variable measures autonomy from political pressure and strength and expertise to govern without any drastic changes in policy or interruptions in government services. Data range is from 0 to 4 , with 0 being lowest BQ and 4 highest BQ data.

Law and Order: This represents the Rule of law variable. This variable reflects the degree to which citizens are willing to accept the established institutions to make and implement laws and adjudicate disputes. Data range is from 0 to 6 with 0 being weak court system and 6 strong court system.

Bureaucratic Quality Index (BQI): This variable represents the average of three variables: Corruption, bureaucracy quality and law and order, with 0 being the lowest quality and 6 the highest quality. According to Mauro (1995) and others, the aggregate of the three variables may yield a better proxy for institutional quality. 
Investment Profile: Factors affecting the risk to investment. These factors include contract viability/expropriation, profit repatriation, and payment delays. 0 represents high risk and 12 is low risk. Expropriation risk: The risk of foreign firms being confiscated or nationalized. Repudiation of contracts by government: Reflects the credibility of government in the enforcement of contracts.

\section{ECONOMETRIC METHODOLOGY}

The study adopts the econometric methodology followed by many cross-country studies, such as Barro (1991), Mauro (1995), and others. The empirical work is applied to a panel of countries in African countries observed over three periods: 1985-90, 1990-1995, and 1995-2000. The use of panel data makes it possible for meaningful empirical research to be carried out even in a case of data limitations in terms of time frame and missing data. In addition, the advantage of dividing the data into sub-periods is to smooth out business cycle effects. Furthermore, the time-dimension of the panel is fairly small in comparison to the number of countries, which helps to avoid some of the complications that may arise in time series data. The regression analysis mainly uses the Generalized Least Square (GLS) method to estimate the equations. However, OLS combined with the White Heteroskedasticity Consistent Covariance methods are also used in some instances as a robustness test ${ }^{6}$. GLS is assumed to yield better results compared to OLS considering the complications in the use of panel data. GLS results are consistent, unbiased, and the estimator has minimum variance. In addition, stacking the data into three sub-periods and applying GLS also corrects another problem faced by panel data namely, serial correlation where endogenous variables are instrumented by their lagged values. By dealing with serial correlation, GLS partially solves the endogeneity, which is another shortcoming in cross-country analysis (Caselli, Esquivel \& Leffort (1996)).

\section{EMPIRICAL RESULTS}

\subsection{Openness, institutional quality, and investment: A simple relationship}

\section{Openness and investment}

Figure 2 presents a scattered diagram of a simple relationship between trade openness and the investment to GDP ratio. A correlation coefficient of 0.5 shows that there is a positive correlation between openness and investment in the period 1980-2000 for the African countries. The correlation is much stronger in mineral rich countries, for example Botswana and Namibia. 


\section{Figure 2 Scattered plots of openness and investment}

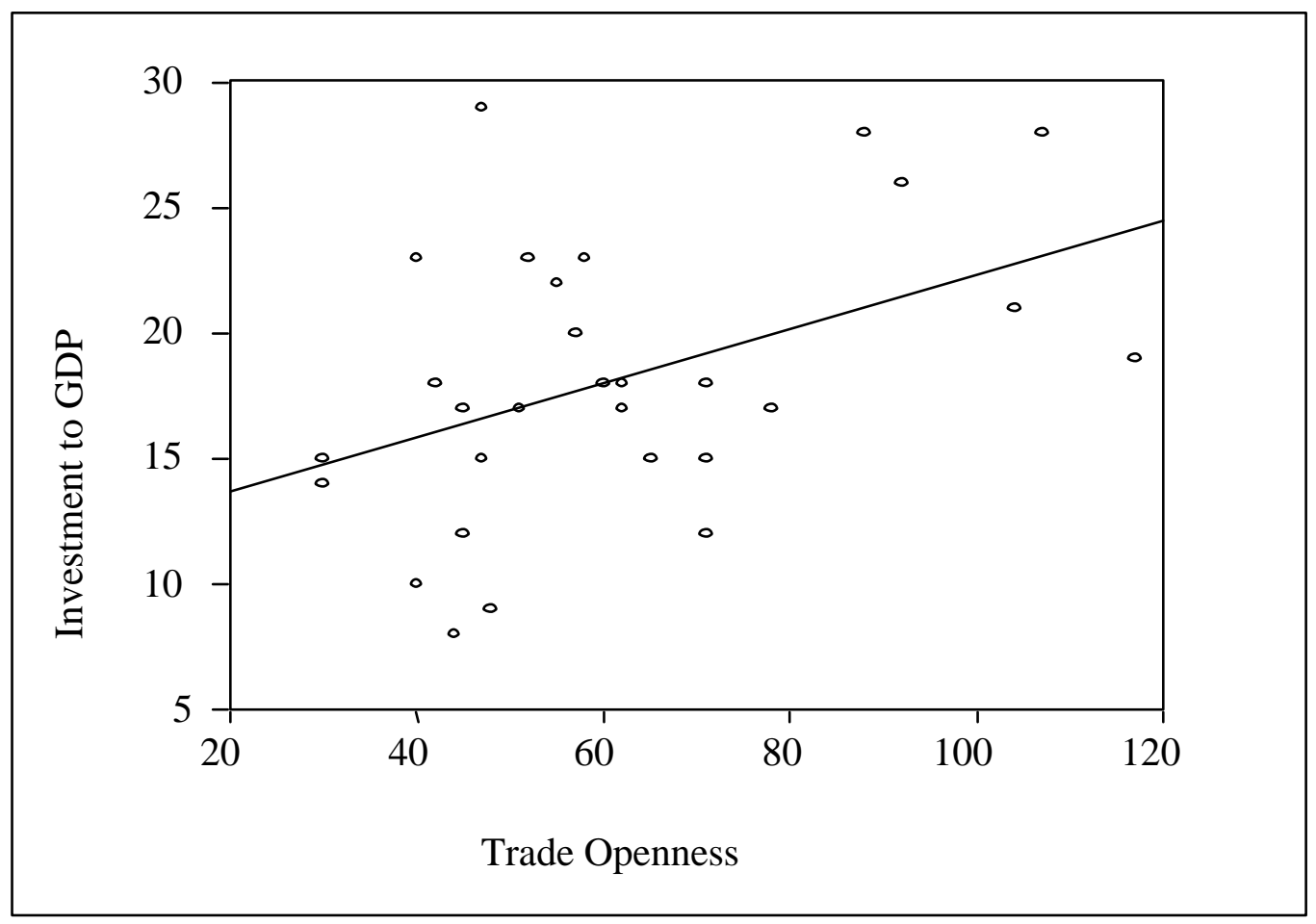

This insight supports the studies by Grossman and Helpman (1991) and Edwards (1992, 1998), among others. These studies provide the intellectual argument that openness could be positively associated with economic performance. One of the contributors in the economic performance of countries in East Asia, such as Korea, Malaysia, and Thailand has been attributed to increase in the volume of trade. With the development of the export sector in the last two decades, East Asia was able to achieve impressive capital accumulation figures. The same explanation also holds for a number of countries in Latin America, such as Mexico, Brazil, Venezuela, and Argentina.

This study supports the argument that openness to trade is good for investment. However, the task at hand is to exercise a caution that increasing openness to trade combined with underdeveloped or malfunctioning institutions can be detrimental to investment. The next section gives a simple empirical analysis of how this can occur.

\subsection{Model specification and regression results}

\section{Model specification}

The model specification follows the cross-country studies by Mauro (1995), Ades and Di Tella (1997a) and many others. Ades and Di Tella (1997a) use a similar technique (using interaction terms) to test the impact of industrial policy on investment, in the presence of corruption. This section presents the results of 
the direct and indirect impact of increased openness and institutional quality on investment.

$$
\gamma_{\mathrm{it}}=\alpha_{1}+\alpha_{2} \text { INST }+\alpha_{3} \text { DOPENESS }+\alpha_{4} \text { INST*DOPENESS }+\alpha_{5} \pi_{\mathrm{it}}+\mathrm{e}_{\mathrm{it}}
$$

where $\gamma_{\text {it }}=$ investment to GDP ratio in ith country at time $\mathrm{t}$

INST $\quad$ institutional quality variable

DOPENESS = A dummy variable with a value of 1 if the value of openness is greater than the mean. This represents countries which are more open to trade

$\pi_{\mathrm{it}} \quad=$ Control variables (initial GDP per capita PPP adjusted, secondary and tertiary education, population growth, inflation rate, and government consumption).

$\mathrm{e}_{\mathrm{it}} \quad=$ random error

from equation 1 the marginal effect of increased openness on investment is

(13) $\partial\left(\gamma_{\text {it }}\right) / \partial$ Dopenness $=\alpha_{3}+\alpha_{4}$ INST

We assign the mean for institutional quality index as the value for INST.

The model specification in equation (12) is estimated using Generalized Least Square (GLS). The main reasons for using this methodology are to correct for some level of serial correlation and heteroscedasticity. The next section presents regression results of the impact on investment of the interaction between institutions and increased openness.

\section{Regression results}

The goal of this section is to examine if the pattern of data in the sample of African countries shows that institutional quality may affect the impact of increased openness on investment. Table 2 presents the results from the regression analysis using the general specification in equation (1). The results show that increased openness has a significantly positive direct impact on investment and an indirect impact through institutions. The total effect of openness on investment is reduced when the interaction variable is introduced. 
This shows that even though openness is good for investment, the total benefits can be reduced by the quality of institutions. The regression results in models 1 and 2 presents results for only investment, openness, and institutions without introducing control variables. In both models increased openness to trade has a significantly positive impact on investment, with estimated coefficients, $12.000(1.336)$ in the first model and 9.967 (3.083). One standard deviation increase in openness improves investment by 6 percent and about 5 percent in models 1 and 2, respectively. Institutional quality also has a significantly positive impact on investment. A one standard deviation increase in institutional quality variable results in an increase in investment by 1.59 percent and 1.79 percent in models 1 and 2.

The marginal impact of increased openness on investment (equation 2) is also positive. However, the coefficient reduced substantially, with coefficients, 4.52 in model 1 and 4.73 in Model 2. Clearly, the total benefits of increased openness in the two cases have declined significantly due to the institutional quality. As indicated by the goodness of fit, the study considers GLS results to be more accurate than those of OLS. Also, GLS results are consistent, unbiased, and the estimator has minimum variance. In addition, stacking the data into three subperiods and applying GLS also corrects the issue of serial correlation. Dealing with serial correlation, GLS partially solves the endogeneity, which is another shortcoming in cross-country analysis.

Model 3 introduces control variables, initial GDP, secondary school education, tertiary education, inflation rate, population growth, and government expenditure. The total impact of increased openness on investment has a positive coefficient, 2.92, which amounts to approximately 4 times below the direct impact of increased openness on investment. One standard deviation improvement in the interaction between institutional quality and increased openness leads to an increase in investment by 6.69 percent as opposed to 4.74 percent from the openness only. Model 4 includes Sub-Saharan Africa to the control variables in Model 3. The direct and the indirect impact of openness on investment has a coefficient, 3.83, an estimate also significantly lower than the direct increased openness coefficient, 9.56. The difference between models 3 and 4 is that, education variables become statistically insignificant when countries in North Africa (Egypt, Morocco, Tunisia, and Algeria) are removed from the sample. Model 5 omits South Africa from the total sample. The overall impact of increased trade on investment is still lower than that the case without the impact of institutions, with a coefficient, 3.58. The only variable that changes is tertiary education, which moves from being insignificant in Model 4 to significant in Model 5. 
Table 2 Regressions for investment, openness, and institutional quality

Dependent Variable: Investment to GDP ratio

\begin{tabular}{|l|c|c|c|c|c|c|c||}
\hline $\begin{array}{l}\text { Independent } \\
\text { Variable }\end{array}$ & $\begin{array}{c}\text { Model 1 } \\
(\mathbf{O L S})^{1}\end{array}$ & $\begin{array}{c}\text { Model 2 } \\
(\mathbf{G L S})\end{array}$ & $\begin{array}{c}\text { Model 3 } \\
(\mathbf{G L S})\end{array}$ & $\begin{array}{c}\text { Model 4 } \\
(\mathbf{G L S})\end{array}$ & $\begin{array}{c}\text { Model 5 } \\
(\mathbf{G L S})\end{array}$ & $\begin{array}{c}\text { Model 6 } \\
(\mathbf{G L S})\end{array}$ & $\begin{array}{c}\text { Model 7 } \\
(\text { GLS) }\end{array}$ \\
\hline Constant & $13.377^{*}$ & $14.496^{*}$ & $10.220^{*}$ & $13.820^{*}$ & $7.450 * *$ & $16.206^{*}$ & $10.155^{*}$ \\
$(2.793)$ & $(1.180)$ & $(2.790)$ & $(3.150)$ & $(3.397)$ & $(2.925)$ & $(2.870)$ \\
\hline Trade Openness & $12.000^{*}$ & $9.967^{*}$ & $9.550^{*}$ & $9.560^{*}$ & $9.656^{*}$ & $8.749^{*}$ & $13.518^{*}$ \\
& $(4.391)$ & $(3.083)$ & $(2.980)$ & $(3.070)$ & $(3.021)$ & $(2.830)$ & $(3.578)$ \\
\hline Institutional & $2.120^{*}$ & $1.811^{*}$ & $1.250^{*}$ & $0.880^{*}$ & $1.302^{*}$ & & \\
quality & $(0.834)$ & $(0.329)$ & $(0.390)$ & $(0.390)$ & $(0.409)$ & & \\
\hline Openness*Insti- & $-2.336^{* * *}$ & $-(1.636)^{* * *}$ & $-2.070^{*}$ & $-1.790^{*}$ & $-1.899^{* *}$ & & \\
tutional quality & $(1.336)$ & $(0.846)$ & $(0.810)$ & $(0.830)$ & $(0.832)$ & & \\
\hline Initial GDP & & & $0.990^{*}$ & $1.310^{*}$ & $0.930 * *$ & $0.992^{*}$ & $1.153^{*}$ \\
& & & $(0.340)$ & $(0.360)$ & $(0.345)$ & $(0.333)$ & $(0.317)$ \\
\hline Secondary & & & $0.070^{* *}$ & 0.004 & 0.055 & 0.049 & $0.074^{*}$ \\
education & & & $(0.030)$ & $(0.040)$ & $(0.0361)$ & $(0.035)$ & $(0.033)$ \\
\hline Tertiary & & $-0.130^{* *}$ & -0.044 & $-0.102 * * *$ & $-0.160^{*}$ & $-0.178^{*}$ \\
education & & & $(0.050)$ & $(0.055)$ & $(0.057)$ & $(0.058)$ & $(0.056)$ \\
\hline Inflation rate & & & $-0.001^{* * *}$ & $-0.001^{* * *}$ & $-0.001^{* * *}$ & $-0.002^{* * *}$ & $-0.001^{* * *}$ \\
& & & $(0.000)$ & $(0.000)$ & $(0.000)$ & $(0.001)$ & $(0.000)$ \\
\hline Population & & & $-1.070^{* *}$ & $-1.553^{*}$ & $-1.340 * *$ & $-2.005^{*}$ & $-1.468 *$ \\
growth & & & $(0.510)$ & $(0.536)$ & $(0.553)$ & $(0.544)$ & $(0.518)$ \\
\hline Government & & & 0.020 & 0.143 & 0.022 & 0.026 & -0.040 \\
expenditure & & & $(0.090)$ & $(0.094)$ & $(0.085)$ & $(0.076)$ & $(0.0834)$ \\
\hline
\end{tabular}


Table 2 continued

\begin{tabular}{|c|c|c|c|c|c|c|c|}
\hline $\begin{array}{l}\text { Independent } \\
\text { Variable }\end{array}$ & $\begin{array}{l}\text { Model 1 } \\
\text { (OLS) }\end{array}$ & $\begin{array}{l}\text { Model 2 } \\
\text { (GLS) }\end{array}$ & $\begin{array}{l}\text { Model } 3 \\
\text { (GLS) }\end{array}$ & $\begin{array}{ll}\text { Model } & 4 \\
\text { (GLS) } & \end{array}$ & $\begin{array}{ll}\text { Model } & 5 \\
\text { (GLS) } & \end{array}$ & $\begin{array}{l}\text { Model } 6 \\
\text { (GLS) }\end{array}$ & $\begin{array}{l}\text { Model } 7 \\
\text { (GLS) }\end{array}$ \\
\hline $\begin{array}{l}\text { Sub-Saharan } \\
\text { Africa }\end{array}$ & & & & $\begin{array}{l}-3.97 * \\
(0.415)\end{array}$ & & & \\
\hline $\begin{array}{l}\text { Sub-Saharan } \\
\text { Africa (without } \\
\text { South Africa) }\end{array}$ & & & & & $\begin{array}{c}3.912 * * * \\
(2.512)\end{array}$ & & \\
\hline Corruption & & & & & & $\begin{array}{c}0.587 \\
(0.561)\end{array}$ & \\
\hline Corruption*trade & & & & & & $\begin{array}{l}-1.699^{*} \\
(0.084)\end{array}$ & \\
\hline $\begin{array}{l}\text { Corruption } \\
\text { investment profile }\end{array}$ & & & & & & & $\begin{array}{l}1.259^{*} \\
(0.390)\end{array}$ \\
\hline $\begin{array}{l}\text { Corruption } \\
\text { investment } \\
\text { Profile * Trade }\end{array}$ & & & & & & & $\begin{array}{l}-2.361^{*} \\
(0.7114)\end{array}$ \\
\hline$?_{3}+?_{4}$ INST & 4.525 & 4.732 & 2.926 & 3.832 & 3.579 & 3.492 & 3.205 \\
\hline $\begin{array}{l}\text { Adjusted R- } \\
\text { Squared }\end{array}$ & .17 & .96 & .93 & .96 & .92 & .94 & .94 \\
\hline $\begin{array}{l}\text { Number of } \\
\text { observations }\end{array}$ & 98 & 98 & 80 & 80 & 80 & 78 & 80 \\
\hline
\end{tabular}

Note: ${ }^{1}$ OLS with White Heteroskedasticity Consistent Covariance

* 1 percent confidence level

** 5 percent confidence level

*** 10 confidence level 
Models 6 and 7 include other measures of institutional quality variables such as corruption and investment profile to test if the results are robust. In the case of corruption (Model 6), the total impact has a coefficient, 3.49. The estimate is not too far from the estimates in the previous columns. Intuitively, the coefficient is smaller because the variable captures only a small aspect of institutional quality as compared to the more comprehensive institutional quality index. Model 7 has the largest direct and the lowest indirect impact of openness to trade on investment compared with the previous columns. Institutional quality in this case is represented by an average between corruption and investment profile. The direct impact estimate is 13.56 and the total effect has the coefficient, 3.20. This increase in magnitude means that increased openness is much more effective when countries have less corruption, as well as conditions where there is no risk of foreign firms being confiscated or nationalized and credibility of government in the enforcement of contracts. One standard deviation increase in openness would lead to an increase in investment by only 6.70 percent, and the inclusion of the institutional variables by 10.43 percent. Overall, the 7 models have demonstrated that for trade openness to be more successful, the quality of institutions plays an important role. In the case of this sample of African countries, the quality of institution appears to cause a reduction in the overall benefits from trade.

In order to show that using the dummy variables present a much stronger case for increased openness than using the actual variable (trade to GDP ratio), an extra regression was run. The results presented in Appendix 1, Table 1 indicate that the statistically significant coefficients on openness $(0.145(0.388))$ and interaction terms Openness*Institutional quality $(-0.047(0.011))$ are much smaller than the coefficients in Model 3. This also shows that restrictive model (model with an openness dummy) yields more compelling results.

Overall, the 7 models in Table 2 have demonstrated that for trade openness to be more successful, the quality of institutions plays an important role. In the case of this sample of African countries, the quality of institution appears to cause a reduction in the overall benefits from trade.

\section{CONCLUSION}

The regression results have provided an important insight in the discussion on openness to trade. The analysis supports the argument that markets that are more open are likely to create significant economic welfare gains through more efficient allocation of resources (static gains). With efficient use of resources, dynamic gains are expected in the longer term with enhanced productivity and investments. Openness to trade in this study has a significantly positive direct 
and indirect impact on investment. However, the total impact of openness to trade on investment is reduced by the indirect impact which is through the quality of institutions. Controlling for variables such as initial GDP, education levels, inflation, population growth, among others, the total impact of increased openness has a positive coefficient approximately 4 times below the direct impact of increased openness on investment. Improving the interaction between the quality of institutions and increased openness by one standard deviation would lead to an increase in investment by 6.69 percent as opposed to 4.74 percent from openness directly. Using the combination of corruption and investment as proxies for institutional quality, one standard deviation increase in openness alone would lead $\mathrm{t}$ an increase in investment by only 6.70 percent, while openness indirectly through institution by 10.43 percent. Intuitively, the message of this study is that, openness to trade will yield optimal benefits if the quality of institutions is improved substantially. Less corruption, better investment profile, less delays, and better rule of law have the potential to contribute to increased gains from openness to trade. Therefore, even though the issues dealing with market access, domestic support, competition, and other trade liberalization policies are very important, other development issues such as institutional quality should be taken into consideration for liberalization to yield fruitful results in Africa. 


\section{Appendix 1}

Figure 1 Corruption and openness to trade

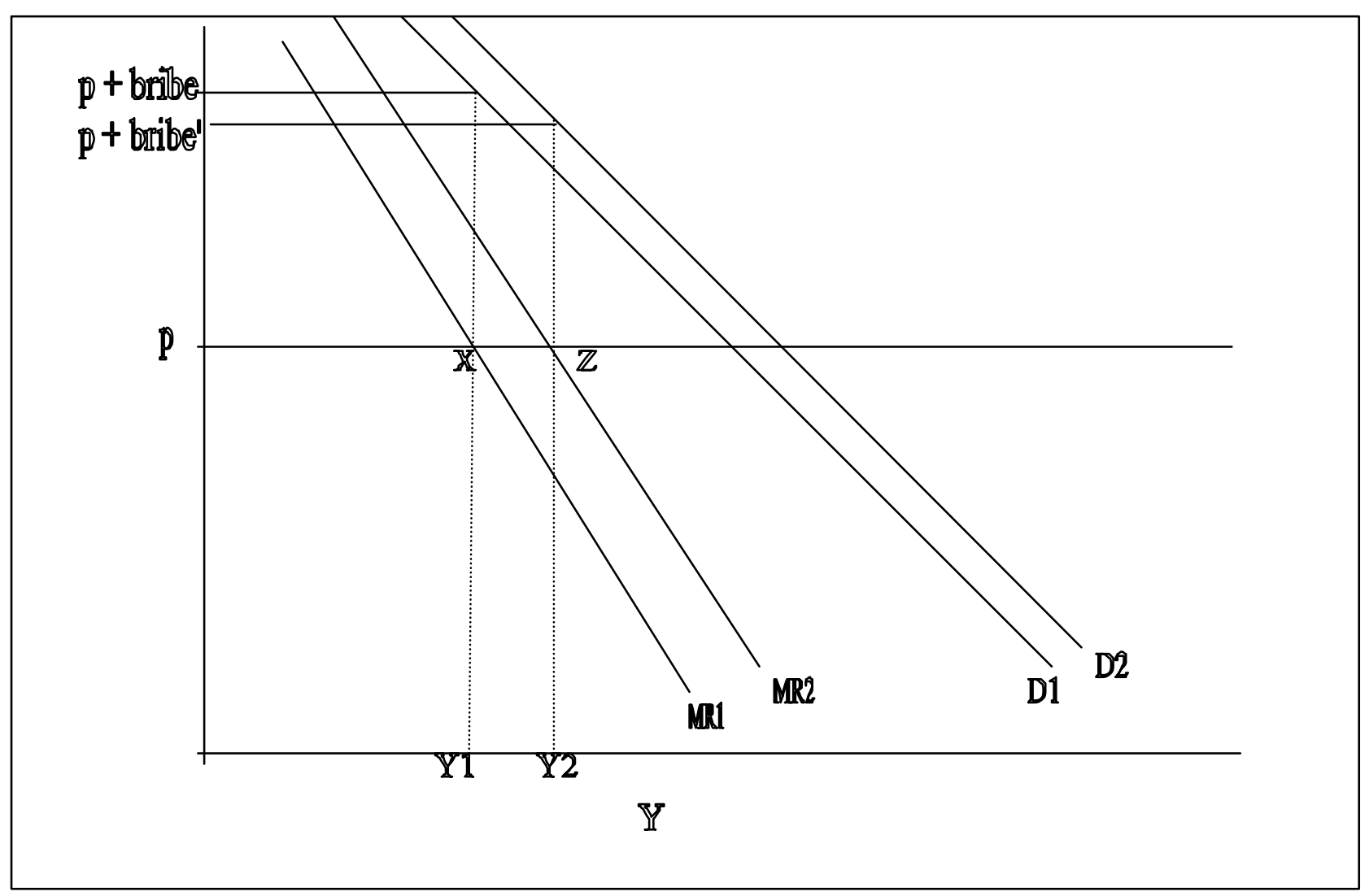


Table 1 Regressions for investment, openness, and institutional quality dependent variable: investment

\begin{tabular}{|c|c|c|}
\hline Independent variable & $\begin{array}{c}\text { Model 1 } \\
\text { (GLS) }\end{array}$ & Model 2 \\
\hline Constant & $\begin{array}{l}10.220^{*} \\
(2.790)\end{array}$ & 3.223 \\
\hline Trade openness(dummy) & $\begin{array}{l}9.550^{*} \\
(2.980)\end{array}$ & \\
\hline Trade openness (Trade/GDP) & & $\begin{array}{c}0.145 \\
(0.038)^{*}\end{array}$ \\
\hline Institutional quality & $\begin{array}{l}1.250 * \\
(0.390)\end{array}$ & $\begin{array}{l}3.600 * \\
(0.039)\end{array}$ \\
\hline Openness*institutional quality & $\begin{array}{l}-2.070^{*} \\
(0.810)\end{array}$ & $\begin{array}{l}-0.011^{*} \\
(-4.067)\end{array}$ \\
\hline Initial GDP & $\begin{array}{l}0.990 * \\
(0.340) \\
\end{array}$ & $\begin{array}{c}0.785 \\
(2.781)^{*}\end{array}$ \\
\hline Secondary education & $\begin{array}{c}0.070 * * \\
(0.030)\end{array}$ & $\begin{array}{c}0.088 \\
(0.032)^{*}\end{array}$ \\
\hline Tertiary education & $\begin{array}{c}-0.130 * * \\
(0.050)\end{array}$ & $\begin{array}{l}-0156^{*} \\
(0.057) \\
\end{array}$ \\
\hline Inflation rate & $\begin{array}{c}-0.001 * * * \\
(0.000)\end{array}$ & $\begin{array}{c}-0.001 \\
(0.001)^{* * *}\end{array}$ \\
\hline Population growth & $\begin{array}{c}-1.070 * * \\
(0.510)\end{array}$ & $\begin{array}{l}-1.212^{*} \\
(0.398)\end{array}$ \\
\hline Government expenditure & $\begin{array}{c}0.020 \\
(0.090)\end{array}$ & $\begin{array}{c}0.141 \\
(0.067)\end{array}$ \\
\hline Adjusted R-squared & .93 & .97 \\
\hline Number of observations & 80 & 80 \\
\hline
\end{tabular}

Note: ${ }^{1}$ OLS with white heteroskedasticity consistent covariance

$* 1$ percent confidence level

** 5 percent confidence level

$* * * 10$ confidence level 


\section{Appendix 2}

\section{Other Variables}

Investment (Gross capital formation)

Outlays on additions to the fixed assets (land improvements; plant, machinery, and equipment purchases; and construction of roads, railways, and buildings) of the economy plus net changes in the level of inventories (stocks of goods held by firms).

\section{Inflation (consumer prices (annual percentage))}

Inflation as measured by the consumer price index reflects the annual percentage change in the cost to the average consumer of acquiring a fixed basket of goods and services that may be fixed or changed at specified intervals, such as yearly.

\section{Gross Domestic Product (GDP) Purchasing Power Parity (PPP) adjusted}

The sum of the gross value added by all resident and nonresident producers in the economy plus any taxes and minus any subsidies not included in the value of the products. GDP is calculated without making deductions for depreciation of fabricated assets or for depletion and degradation of natural resources. Value added is the net output of a sector after adding up all outputs. The industrial origin of value added is determined by the International Standard Industrial Classification (ISIC). The Gross Domestic Product is converted to international dollars using the purchasing power parity rates. GDP per capita is Gross Domestic Product divided by midyear population. Growth rates are calculated as annual averages and represented as percentages.

\section{Openness to trade (Trade/ PPP GDP)}

The sum of merchandise exports and imports in current U.S. dollars divided by the value of GDP converted to international U.S. dollars using purchasing power parity conversion factors. This variable represents volume of trade as a share of PPP GDP.

\section{Population}

Total population of an economy includes all residents regardless of legal status or citizenship except for refugees not permanently settled in the country of asylum, who are generally considered part of the population of their country of origin. Annual population growth rate is the exponential change for the indicated 
time period. The exponential growth rate is the growth between two periods and is calculated as follows:

Growth rate $=\ln \left(\mathrm{p}_{\mathrm{n}} / \mathrm{p}_{1}\right) / \mathrm{n}$

Where $p_{n}$ and $p_{1}$ are the last and first observations in the period, $n$ is the number of years in the period, and in is the natural logarithm operator. The growth rate is based on the model of continuous, exponential growth between two points in time.

\section{Gross enrolment ratio}

Is the rate of total enrolment, regardless of age, to the population of the age group that officially corresponds to the level of education specified. Secondary school provides specialized instruction at middle secondary, or high schools, teacher training schools; this level of education is based on at least four years of instruction at the primary level. Tertiary education, whether or not to an advanced research qualification, normally requires, as a minimum condition of admission, the successful completion of education at the secondary level. The enrollment ratios are important indicators of the size and capacity of a country's education system and may be useful measures of education outcomes. The World Bank obtained the enrollment ratios for the United Nations Educational, Scientific, and Cultural Organization's (UNESCO) Statistical Yearbook 1997.

\section{Government consumption (Government Expenditure/GDP)}

Government expenditure includes non repayable current and capital expenditure as a share of GDP. It does not include government lending or repayments to the government or government acquisitions of equity for public policy purposes. The World Bank obtained the data from the International Monetary Fund's (IMF) Government Finance Statistics Yearbook 1996. Each country's accounts are reported by using a system of common definitions and classifications found in the IMF's Manual on Government Finance Statistics (1996). 


\section{ENDNOTES}

1 We would like to thank the referees, Arsene Aka, Roberta Hollader, Lieffu Huang, Merlinda Ingco, Ransford Palmer and the participants at the 2002 Annual Conference on Econometric Modelling for Africa for their helpful comments and suggestions.

2 Delays in the process of obtaining public goods, such as licenses in known as red tape.

3 This environment is characterized as having a very weak rule of law.

4 For more information on the government corruption index, bureaucratic index, and the contract enforcement variables see Knack and Keefer (1995) or Keefer and Knack (1997).

5 For more information on the government corruption index, bureaucratic index, and the contract enforcement variables see Knack and Keefer (1995) or Keefer and Knack (1997).

6 Heteroskedasticity is a common problem in panel data. In these crosscountry studies, the scale of dependent variable and independent variables tend to vary across observations. In other words, the disturbance terms have different variances.

\section{REFERENCES}

1 ADES, A.F. \& GLAESER, E.L. (1999) "Evidence on growth, increasing returns and extent of the market", Quarterly Journal of Economics, 144: 1025-46.

2 ADES, A. \& DI TELLA, R. (1997a) "The new economics of corruption: A survey and some new results", Political Studies, 45: 496-515.

3 (1997b) "National champions and corruption: Some unpleasant interventionist arithmetic", Economic Journal, 107: 1023-1042.

4 ALESINA, A. \& WEBER, B. (1999) "Do corrupt governments receive less foreign aid?" NBER Working Paper 7108, Cambridge, MA.

5 ANDERSON, JAMES, E. \& NEWRY, P. (1994) "Measuring the restrictiveness of trade policy", World Bank Economic Review, 8: 151-69.

6 BALASSA, B. (1982) Development Strategies in Semi-Industrial Countries, Oxford: Oxford University Press.

7 BARRO, R.J. (1991) "Economic growth in a cross-section of countries", Quarterly Journal of Economics 106: 407-443.

8 BARRO, R J. \& SALAI-I-MARTIN, X. (1995a) “Convergence”, Journal of Political Economy, 100: 223-251.

9 (1995b) Economic Growth, New York: McGraw-Hill.

10 BAUMOL, W.J. 1986. "Productivity growth, convergence and welfare", American Economic Review, 76: 1072-85. 
11 BECKER, G.S. \& STIGLER, G. (1974) "Law enforcement, malfeasance, and compensation of enforcers", Journal of Legal Studies, 3: 1-19.

12 BERNARD, A.B. \& JONES, C.I. (1996) "Comparing apples and oranges: productivity convergence and measurement across industries and countries", The American Economic Review, 86(5): 1216-38.

13 BHAGWATI, J.N. (1982) "Directly unproductive, profit-seeking (DUP) activities", Journal of Political Economy, 90: 988-1002.

14 BLISS, C. \& DI TELLA. R. (1997) "Does competition kill corruption?" Journal of Political Economy, 105: 1001-23.

15 CASSELLI, F., ESQUIVEL, G. \& LEFORT, F. (1996) "Reopening the convergence: A new look at cross-country growth empirics", Journal of Economic Growth, 1: 363-89.

16 DOLLAR, D. (1992) "Outward-oriented developing economies really do grow more rapidly: Evidence from 95 LDCs, 1976-85", Economic Development and Cultural Change, 523-44.

17 DOLLAR, D. \& KRAAY, A. (2001) "Trade, growth and poverty", World Bank Working Paper (Washington: World Bank).

18 EDWARDS, S. (1993) "Openness, trade liberalization and growth in developing countries", Journal of Economic Literature 31: 1358-93.

19 FAN, S.C. \& GROSSMAN, H.I. (1998) "Incentives and corruption in Chinese economic reform", Lingnan College, Brown University.

20 GREEN, W.H. (1997) Econometric Analysis, New Jersey: Prentice-Hall, Inc.

21 GROSSMAN, G. \& HELPMAN, E. (1991) Innovation and Growth in the Global Economy, Cambridge: MIT Press.

22 HALL, R. \& JONES, C. (1999) "Why do some countries produce more output per worker than others?", Quarterly Journal of Economics, 144: 83-116.

23 INGCO, M.D. (1997) "Has liberalization improved welfare in leastdeveloped countries? Yes", World Bank Policy Research Paper 1748 (Washington: World Bank).

24 ELLIOTT, D.R. \& PALMER, R. (1999) "What is the relationship between government, exports, and GDP growth? The Jamaica experience explored", Comparative International Development, 34: 40-9.

25 ISLAM, N. (1995) "Growth empirics: A panel data approach", The Quarterly Journal Economics, 110: 1127-70.

26 KANDIERO, T. (2001) "Institutional quality and economic performance", Ph.D Dissertation, Economics Department, Howard University, May.

27 KRUEGER, A.O. (1974) "The political economy of the rent seeking society", The American Economic Review, 64: 291-303. 
28 KNACK, S. \& KEEFER, P. (1995) "Institutions and economic performance: cross country tests using alternative institutional measures", Economics and Politics, 7: 207-27.

29 KNACK, S. \& KEEFER, P. (1997) "Why don't poor countries catch up?", Economic Inquiry, 1115: 590-602.

30 KRUGMAN, P. (1999) The Return of Depression Economics, New York: W.W. Norton \& Company.

31 MANKIW, G., ROMER, D. \& WEIL, D. (1992) "A contribution to empirics to economic growth", Quarterly Journal of Economics 107: 407437.

32 MAURO, P. (1995) "Corruption and growth", Quarterly Journal of Economics, 3: 681-712.

33 MURPHY, K.M., SHLEIFER, A. \& VISHNY, R.W. (1993) "Why is rent seeking so costly to growth?" AEA Papers and Proceedings, 83: 409-15.

34 NELSON, R. (1997) "How new is new growth theory?" Challenge, 40: 29-58.

35 NORTH, D. (1990) Institutions, Institutional Change and Economic Performance, Cambridge, MA: Cambridge University Press.

36 PRITCHETT, L. (1991) "Measuring outward orientation in developing countries: Can it be done", World Bank Policy Research Working Paper (Washington: World Bank).

37 PRITCHETT, L. \& SETHI, G. (1994) "Tariff rates, tariff revenue, and tariff reform: Some new facts", World Bank Economic Review, 8: 1-16.

38 ROMER, P. (1986) "Increasing returns and long run growth", Journal of Political Economy, 94: 1002-37.

39 ROSE-ACKERMAN, S. (1978) Corruption: A Study in Political Economy, New York: Academic Press.

40 SACHS, J.D. \& WARNER, A. (1995) "Economic reform and the process of global integration", Brookings Papers on Economic Activity, 1: 1-118.

41 SACHS, J. D. \& WARNER, A. (1997) "Sources of slow growth in African economies", Journal of African Economies 6: 335-76.

42 SALA-I-MARTIN, X. (1994) "Cross sectional regression and the empirics of economic growth", European Economic Review, 38: 739-47.

43 SHLEIFER, A. (1996) Government in Transition. Cambridge, MA: Harvard University Press.

44 SHLEIFER, A. \& VISHNY, R. W. (1993) "Corruption", Quarterly Journal of Economics 3: 599-617.

45 (1994) "Politicians and firms," Quarterly Journal of Economics 4: 995-1026. 